\title{
Romania needs a strategy for thermal energy
}

\author{
Aureliu LECA \\ Romanian Academy of Technical Sciences, Bucharest, Romania
}

\begin{abstract}
The energy sector in Romania consists of three sub-sectors: electricity, natural gas and heat. Among these, the sub-sector of thermal energy is in the most precarious situation because it has been neglected for a long time. This sub-sector is particularly important both due to the amount of final heat consumption (of over 50\% of final energy consumption), and to the fact that it has a direct negative effect on the population, industry and services. This paper presents the main directions for developing a modern strategy of the thermal energy sub-sector, which would fit into Romania's Energy Strategy that is still in preparation This is based on the author's 50 years of experience in this field that includes knowledge about the processes and the equipment of thermal energy, expertise in the management and restructuring of energy companies and also knowledge of the specific legislation. It is therefore recommended, following the European regulations and practices, the promotion and upgrading of district heating systems using efficient cogeneration, using trigeneration in Romania, modernizing buildings in terms of energy use, using of renewable energy sources for heating, especially biomass, and modernizing the energy consumption of rural settlements.
\end{abstract}

Keywords: strategy, thermal energy, cogeneration, district heating, trigeneration, biomass.

Please cite this article as follows: Leca, A. (2015), "Romania needs a strategy for thermal energy", Management \& Marketing. Challenges for the Knowledge Society, Vol. 10, No. 1, pp. 3-11, DOI: 10.1515/mmcks-2015-0001.

\section{Introduction}

Energy is a product with great economic, social, strategic and political value. It is essential for a country's economy, for its industry, services, and also for its social activities. The lack of access to energy has major consequences. Various oil crises, regional conflicts- that degenerated into wars-, serious energy accidents, social tensions and energy policy errors clearly emphasized in the last 30-40 years the strategic importance and political role of energy .

The energy sector (production, transport, distribution and consumption of resources) is not only of strategic importance for any country, but at the same time it is a major contributor to environment pollution. Thermal energy represents an important part of the energy industry. Thermal energy, which includes public service of centralized heat supply, has a share of over $50 \%$ in energy consumption of Romania, but at the same time it contributes heavily to energy loss. The most important consumers are the 7.6 million residents, who live in 3 million apartments, which represent almost 83,800 blocks of flats (INS, 2011). The main causes for the regression of district heating are institutional, legal, technical and administrative inefficiency and financial shortage.

The most efficient heating model of settlements with multi-story residential buildings is the central supply system which has heat produced by high-efficient cogeneration plants (with efficiency of over 75\%). Compared to separate production of electricity and heat, a cogeneration plant simultaneously generates electricity and heat, making fuel savings of 30-35\%, with a proportional reduction 
of environmental pollution (Leca et al., 2011). The energy strategy of Romania should have provisions concerning the modernization of the thermal energy subsector in all respects for the benefits of consumers and the improvement of its environmental impact.

\section{Guidelines to improve the thermal energy strategy}

Considering the energy industry sector a vital strategic infrastructure for the national energy security, among the three sub-sectors of this industry in Romania electricity, natural gas and thermal energy for municipalities and industry, thermal energy is, by far, the most defective. The main cause for this is the superficial treatment applied in the last 25 years in this sector in urban and also rural areas. This led to an unfavourable accumulation of problems, which are very difficult to solve.

At national level, the final energy consumption in the residential and tertiary sector altogether comprises $45 \%$ of the total energy consumption, and approximately $40 \%$ of greenhouse gas emissions, to which industry consumption must also be added. It must be pointed out that almost half of the Romanian population has no access to any kind of modern heating solution, because of technical reasons, or due to financial issues. Moreover, thermal energy consumption in the industry is an important component, as important as the buildings fund (Leca, 2013a, 2013b).

The improvement of energy efficiency in buildings and, overall, within localities, as well as higher efficiency energy use in industry and services, is essential not only for achieving national objectives relating to sustainable use of natural resources and safety in energy supply, but also to meet the objectives of the EU strategy on climate change and moving to a competitive low-carbon market by 2050 .

The current business model of district heating systems in Romania is not seen as valid in the European Union, given the large number of disconnections that result in heating subsidies for individual heating plants on natural gas. The European Commission believes that, as long as this economic model is not stable and robust, and operators do not guarantee optimal service, EU funded investments in this sector are not justified, and this affects the sustainable development of the energy sub-sector.

The responsibility for the energy system governance is divided among too many institutions, leading to bureaucracy and lack of efficiency. Many experts that are deeply involved in various aspects related to increasing the efficiency of energy consumption in buildings, industry and services, are united by the belief that central and local authorities, having specific responsibilities, must find solutions to accelerate transition to a sustainable energy future for these categories of energy consumers. They share an interest both in heating and cooling (airconditioning), considering the two as a market with significant possibilities for better and more efficient energy integration. This is a market of considerable size, not only in terms of energy consumption, but also in terms of low energy and low carbon emission solutions, available on the short-term, bringing significant costefficient opportunities.

Local production of heat and electricity is an important service to be developed and scaled based on local demand; at the same time it is a complementary service 
MMCKS to large national systems for electricity and natural gas production and transmission.

Furthermore, Romania is a country with natural gas resources. These resources must be used as efficiently as possible. The pricing for volumes sold en detail must reflect the real distribution costs and must highlight the advantages of wholesale consumption. In the future, the permits for connection to natural gas distribution plants will only be granted for buildings designed with individual heating solutions, and to which the connection to a centralized heating system has not been possible.

Therefore, next to a lot of specialists, the author considers that a distinct chapter referred to as 'The strategy for providing thermal energy', must be included in the Energy Strategy of Romania. This strategy should be aimed at preparing and developing the thermal energy market, in a balanced and sustainable manner, for buildings, industry and services, based on increased energy efficiency and renewable energy.

It is of utmost importance for such a strategy to consider the following guidelines: Upgrading district heating and promoting highly efficient cogeneration. Investment funding sources; Promoting centralised air-conditioning; Promoting industrial cogeneration; Upgrading urban buildings for energy purposes; Using renewable energy sources; Increasing energy efficiency in rural localities; Affordability of energy bills.

\section{Upgrading district heating and promoting highly efficient cogeneration. Investment funding sources}

Throughout consolidated free economy countries, centralised district heating has proven to be a sustainable and low-cost method in densely populated urban areas. In transition countries, such as Romania, centralised district heating is relatively widespread, but requires substantial upgrades to become market competitive with regards to performance and price.

The sub-sector of urban cogeneration and thermal energy centralised district heating system has an obvious and alarming regression in Romania. The causes of such regression are numerous: of institutional, legislative, technical, administrative, financial, investment and social nature, influenced by the atypical natural gas price policy. The disconnections from the centralised district heating system, which give rise to individual heating solutions, have been generated by a lack of understanding of this field, both at central and local level. During the past 25 years, the existence of a technical heritage, with high energy losses and a modest living standard, inevitably led to this situation. Moreover, as compared to similar European Union average values, it had almost a continuous decline.

Considering the particular significance of the thermal energy centralised district heating system for the living standard of the population, the following measures are required (Leca, 2013b):

$\checkmark$ an effective institutional and legislative framework, with clear responsibilities regarding the promotion of efficient cogeneration and modern centralised district heating systems; a sole regulatory authority, a ministry responsible with public services, including district heating;

$\checkmark$ improving the cost allocation system and the support scheme by investment premiums, without overcompensation, high efficiency cogeneration, including for rehabilitated plants;

$\checkmark$ increasing awareness of local authorities to obtain investments for upgrading 
cogeneration plants, together with the operator, using the premium for MMCKS efficient cogeneration as a warranty;

$\checkmark$ using the binomial tariff for heat and natural gas, to acknowledge economic realities and for a better monthly distribution of heating operator expenses;

$\checkmark$ complying with legal provisions on unitary heating areas; discouraging disconnections from centralised district heating systems;

$\checkmark$ prioritised use of biomass, knowledge and compliance with investor requirements in the field;

$\checkmark$ VAT reductions for energy efficiency development works;

$\checkmark$ solutions for restructuring the existing systems by concession, as integrated thermal heating systems to experienced private operators;

$\checkmark$ improving the level of public service quality assurance of the heat required, as argument for reconnecting consumers to the centralized system.

The issue of energy in large cities must also include the energy recovered from waste as an important component of non-hazardous solid waste management. The conversion of residual, non-compostable or non-recyclable solid waste into efficient electricity and heat, via cogeneration plants, is seen as a method of using local energy sources and, at the same time, reducing methane generation from landfills. The final wastes resulting from such cogeneration plants comprise approximately $10 \%$ of the initial wastes, having a significant contribution to the reduction of landfill materials. Other major municipalities in Romania should follow the example of the first project of this kind, conducted in Timișoara.

During the 2014-2020 programming interval, funds for investment projects involving large companies in the public and private sector should be granted, without any discrimination. Furthermore, in general, equal eligibility of projects (public and private) is required, provided there is compliance with the EU 2020 Strategy (EU 2020 Strategy, 2010), where Romania has a role to play. In this context, we recommend that European subsidies be also available for providers of environmental and energy efficiency services. These grants would be used, on the one hand, to develop projects in line with EU and Romanian objectives set for the year 2020 (energy efficiency, cogeneration, use of waste as an energy source) and, on the other hand to limit end-user impact of increased costs due to new standards of environmental requirements (the Industrial Emissions Directive and hazardous waste management laws).

\section{Promoting district cooling}

Recently, trigeneration has been increasingly considered as the solution by which cogeneration groups can become efficient also during the summertime, when the heat demand is much lower. The method of obtaining cooling agents from high temperature thermal energy no longer appears to be new information. It is important to promote this solution and to adapt indoor plants in order to accept and use the cooling agent, since technological solutions are already well- known. The first step is to connect large commercial spaces, modern office buildings and new residential buildings to the urban cogeneration and thermal energy centralised district heating systems.

\section{Promoting industrial cogeneration}

Industrial cogeneration in Romania should not be considered a novelty, given that, before 1989, all industrial sites and major cities in our country were supplied with 
MMCKS electricity and heat from large industrial and urban central heating plants, generating approximately $40 \%$ of the total electricity produced in the country. Because of the deindustrialization of Romania that took place in the last 25 years, the electricity generated in heating plants (cogeneration plants) has decreased to 9.5-10.8\% from the total electricity production. Industrial cogeneration brings at least two important advantages: it increases industry competitiveness; it is the best method for decarbonisation of heat used in industry.

Industrial cogeneration must also be promoted by the Romanian Energy Regulatory Authority, which, in terms of increasing economic and energy performance of industrial units, must review certain restrictive Romanian regulations (by comparison with other European states). To this end, the Romanian Energy Regulatory Authority's notification should be reviewed by the European Commission on State Aid, namely with regards to selfconsumption: "Romanian Authorities have stipulated that no support will be granted for electricity [...] used by an enterprise for its own needs (ANRE, 2009).

Unlike Romania, in other EU states, the approach on industrial cogeneration is totally different. Hence, in Germany, the legal framework on industrial cogeneration plant (2012) has the following main provisions: a) it only offers support for new and upgraded cogeneration plants, according to Directive 2004/4/EC; b) it grants support by payment of a significant bonus for each kWh of electricity produced (for self-consumption of delivered to the public network); c) it grants additional support for investments on centralised heating and cooling; d) it grants additional support on thermal energy storage for heating and cooling purposes (Law CHP, 2012).

Within the position paper of May 8th, 2013 on the 'Potential role of industrial cogeneration in the energy sector and within the strategy of European industry for 2030/2050', as well as that of September 17th, 2014 COGEN Europe stated two basic principles that need to be acknowledged, namely: a) industrial cogeneration increases industry competitiveness; b) industrial cogeneration is the best method for decarbonisation of heat used in industry.

\section{Upgrading urban buildings for energy efficiency}

Romania has 4.6 million homes in urban areas, of which approximately 3 million are apartments, $97 \%$ private properties and 7 million residents, located in approximately 79,000 multi-storied buildings. The structure of energy consumption of a home is: $57 \%$ heating, $25 \%$ hot water for consumption, $11 \%$ electricity, 7\% cooking.

In multi-storey residential buildings, the specific thermal energy consumption reaches an average of $250-300 \mathrm{kWh} /$ (sqm.year), two times higher than the EU average. The buildings' heat losses amount to $40-50 \%$ of the final energy consumption. About $75 \%$ of the buildings are old, as they were built 40-55 years ago. The nominal average wage of tenants is $16 \%$ of the EU average, and the utility prices are almost equal to EU average, so the ratio of energy bills is less affordable as compared to their income.

Although the energy rehabilitation of buildings has high energy, cost, social and environmental impact advantages, only 5-6\% of multi-storey buildings are currently rehabilitated from an energy efficiency point of view, as a consequence to the lack of funding sources for such works. The reasons for this slow process are the lack of sufficient funds, and the inefficient financing schemes implemented 
until now. The cost of thermal rehabilitation works for approximately $2 / 3$ of the buildings is rated at almost EUR 5 billion on a 15 years period. ( $50 \%$ by $2020,25 \%$ by $2025,25 \%$ by 2030 ) (Leca, 2013a).

With several exceptions, the upgrade of the buildings energy efficiency has not constituted a major concern for the central and local authorities,. In consequence, the liberalization of electricity, natural gas and heat prices has become a major social problem because of the general poverty of Romanians, as compared to the average EU revenues.

Given the above, the competent central and local authorities must urgently find, financial solutions to accelerate the buildings' upgrade works, including the use of European Structural Funds and, and they also must set out welfare measures for disadvantaged residential consumers. It is imperative to monitor the effects of such investments both with regards to the magnitude of energy poverty, but also on health and welfare budgets.

The energy efficiency upgrading programs must view as a priority social housing for multiple families and old buildings because this way the energy savings are the highest, and, by rehabilitation, the risk of energy poverty decreases exactly for the category of tenants having the lowest income. Therefore the energy efficiency of buildings is both a problem of large-scale energy efficiency, as well as a very urgent social problem, reassessed by the latest EU directives.

\section{Using renewable energy sources}

Promoting renewable energy sources (RES) is an obligation of all EU Member States, including Romania. Law 220/2008, using a particularly generous support scheme based on green certificates, achieved this goal. The result was the disproportionate installation of capacities to generate electricity, throughout approximately 2.5 years, using wind and photovoltaic energy and, to a lesser extent, hydroelectric energy. While amounting to $52 \%$ of the national RES potential, biomass and biogas, the only sources for thermal energy generation (cogeneration or directly) have covered only $2 \%$. This potential, entirely Romanian, practically unused for energy purposes, comprises 6.38 million hectares of forests, which require cutting and cleaning maintenance works and over 1 million hectares of land unsuitable for agricultural work, but suitable for energy crops; to which the biogas obtained from fermentation and urban waste processes is added. The tragedy of this national resource, namely forests, consists of logging, illegal timber theft and recovery, so that the forest destruction reached unspeakable limits for the benefit of foreign companies (Leca et al., 2013).

Currently, forestry is under-developed because several barriers are affecting it: inadequate legislation, out-dated technical norms, institutional inefficiency and lack of control (particularly for state-owned forests), poor quality of infrastructure (roads), etc. In rural areas, firewood is used both for heating and cooking. For such applications, using more efficient equipment (e.g. efficient stoves) for burning would lead to a more efficient use.

In a moderate projection $10 \%$ of the total electricity produced in Romania, and the current heat demand for product heating in all district heating systems of Romania. It must be emphasized, in particular, that biomass exploitation for energy purposes, as a fully local resource, directly contributes to increased national energy safety, representing an alternative to the use of domestic or imported natural gas. 
According to Directive 2012/27/EU, an efficient district heating and cooling system uses at least $50 \%$ energy from renewable sources, $50 \%$ residual heat, $75 \%$ cogenerated thermal energy or $50 \%$ from an energy-heat combination of the above-mentioned nature.

In terms of opportunities and recommendations, it is imperative for Romania to develop the long overdue national strategy on forests. This should define a framework for the economic use of forests, while also outlining their conservation policy. By means of an adequate strategy, it is possible to combine environmental, social and economic aspects of forest management, as demonstrated by examples from other EU countries. Biomass-based economy can provide jobs and income for the rural population, where employment conditions are harsh. At the same time, it can generate significant revenues for the domestic economy. It is preferable for biomass energy to be used in small and medium cogeneration heating plants (of 5 to $10 \mathrm{MWe}, 10-30 \mathrm{MWt}$ ), located in the vicinity of their production areas. This will maintain the transportation cost and the infrastructure requirements at reasonable levels. One last aspect is that biomass should be used for high-efficiency cogeneration, considering the financial and environmental aspects (health) and those on the lead consumer's long-term existence (industrial centre or the district heating system).

\section{Energy efficiency in rural areas}

Rural energy efficiency, although mentioned in some national energy draft strategies, did not represent a considerable concern for central or local authorities, so far, this being reflected in the modest housing and living conditions. Wood biomass, obtained by purchase or illegally, is the main fuel used for stove heating, often rudimentary ones, having an efficiency of around 20-30\%. For most families, electricity is included in the social consumption; there are still nearly 100 isolated villages without electricity, comprising approximately 100,000 households.

There are numerous energy saving solutions in rural areas, but their application depends directly upon access to funding sources, which so far have been practically zero. Unfortunately, rural areas are old, considering their elderly population, under an obvious process of exclusion, and the youth is often working abroad. The energy efficiency upgrade works that are most commonly based on savings from family members working abroad, the investment is recovered within an interval of one year to twenty years (Ministerul Economiei, 2011).

Flue gas recovery solutions should be promoted, as well as efficient cooking techniques. For existing buildings, measures can be taken to reduce heat losses during the cold season and excessive heating during the warm season. These measures include roof insulation (relatively low-priced) and wall insulation, the use of double-glazed windows, door and window seals. The costs and benefits of each measure, the financial incentives and the payments by instalments shall be assessed. For new buildings in rural areas, the standards of buildings' thermal insulation must be adhered to and continually improved.

New ovens can reach outputs of at least $60 \%$, but they are expensive for the population of rural areas. They require analyses on the oven condition and the biomass usage degree, as well as a public program for supporting the installation of new ovens for eligible social groups. Efficient lamps for street lighting or the lighting of public buildings must become mandatory. The use of photovoltaic 
energy is most often the optimal solution, as long as the money for its installation can be provided. There are a wide variety of measures to increase energy efficiency in rural
areas, many of them being specific, with significant effect in increasing housing conditions. These include analyses and studies carried out on the structure and level of energy use, especially in homes, analyses and studies to be carried out by specialized institutions, the assistance and insurance costs being borne by central authorities.

There is a range of renewable energy sources that can be used in the power supply of rural areas, namely: biomass is the main rural fuel, being mostly used for house and water heating, as well as cooking; biomass can be generally used to generate electricity, and it can be converted into biogas for cooking or lighting. Micro-hydro power plants can be a basic option for supplying rural areas that are not connected to the electricity network. Wind energy, which can be used including in rural areas with no electricity, together with energy storage systems. Solar energy can save fossil fuels for heating up water or generating electricity and, therefore, it reduces $\mathrm{CO}_{2}$ emissions.

The sources for project funding also include the following: The EU Green Fund, which can cover up to half of the capital costs for electricity generation projects; the European Regional Development Fund, research funds, the Romanian Energy Efficiency Fund and others. It should however be acknowledged that rural development, in general, and energy efficiency in particular, are operations of particular difficulty and it is uncertain whether the authorities will be able to address them.

\section{Affordability of energy bills}

The gradual liberalization of the electricity and natural gas market in Romania is carried out in the context of an unsustainable energy sector, facing a series of difficulties, including high energy losses and extensive 'energy poverty'. On a medium term, the process of electricity market liberalization leads to a considerable increase in electricity, natural gas and heat prices, a process that will put a high pressure on the capacity of all energy consumers (industrial and residential) to pay energy bills (Leca et al., 2013).

The results of a simple analysis show an important increase in state efforts to support vulnerable consumers. The increase is caused by two reasons: a) increasing the bill value in a higher dynamic than the potential revenue increase by indexing and $\mathrm{b}$ ) increasing the number of vulnerable consumers by new categories of consumers reaching the energy poverty situation. An obvious, rather uncomfortable solution would be to reduce energy consumption by increasing energy efficiency or by reducing energy losses, and this should be the main goal of the energy efficiency policy. Even under such conditions, it is likely for the number of vulnerable consumers to increase and, therefore, the increase of family incomes due to accelerated economic growth remains one of the important factors to balance the situation.

Finally, the current social welfare system must be reviewed in view of finding a methodology for accurate assessment of energy poverty and proper sizing of necessary social aids. This should take into account, first, the demand for heating, properly calculated, by type of building, climate area, the building envelope condition, etc. (which is not achieved by the current methodology). This should 
MMCKS highlight the link between the benefits of investments in upgrading the buildings and apartments, and the budget for state aids, namely, the health budget.

One alternative that should not be neglected is the VAT reduction for the centralised district heating system, according to the model of several EU Member States, namely: France (general VAT/centralised district heating VAT = 20\%/5.5\%), Greece (23\%/13\%), Ireland (23\%/13.5\%), Latvia (21\%/12\%), Lithuania (21\%/9\%), Luxembourg (15\%/12\%), Hungary (27\%/5\%), with beneficial effects especially on vulnerable consumers.

\section{Conclusions}

A distinct chapter referred to as 'The strategy for providing thermal energy', must be included in Romania's Energy Strategy, aimed at preparing and developing the thermal energy market, in a balanced and sustainable manner, for buildings, industry and services, based on increased energy efficiency and renewable energies. The administrative framework on the energy system governance requires an increase in efficiency to reduce bureaucracy and inefficiency of public institutions, as well as to ensure the stability and predictability of the legal and regulatory framework. For public interest, as the receiver of the public service for the centralised heating system, further European funding of projects is absolutely essential, as well as promoting investments in centralized heating systems in our cities, during the second stage of investment funding, for their sustainable development and for compliance with commitments made by Romania as a Member State of the European Union (increasing energy efficiency, decreasing pollution and reducing energy dependence).

\section{References}

European Commission (2010), "Communication from the Commission, Europe 2020 - A strategy for smart, sustainable and inclusive growth”, Brussels.

INS, "Recensământul populației și locuințelor", 2011, www.ins.ro.

Law CHP, KWK-G 2012, Germany.

Leca, A. and Cremenescu, C. (2011), Serviciul public de încălzire centralizată, AGIR, București.

Leca, A. (2013a), "Propuneri de îmbunătățire a cadrului legislativ de promovare a cogenerării de înaltă eficiență în scopul creșterii atractivității acestuia pentru mediul investițional, în legătură cu prevederile Directivei 2012/27/CE privind eficiența energetică", Contract nr. 65/17.05.2013, ANRE, București.

Leca, A. (2013b), "Propuneri privind modalități de implementare a soluțiilor de îmbunătățire a cadrului legislativ de promovare a cogenerării de înaltă eficiență, în scopul creșterii atractivității acestuia pentru mediul investițional, în corelare cu prevederile Directivei 2012/27/CE privind eficiența energetică", Contract nr. 105/19.09.2013, ANRE, București.

Leca, A., Mușatescu, V., Ionescu, V., Tobescu, F. and Gușilov, E. (2013), "Liberalizarea treptată a piețelor de energie electrică și gaz asupra economiei românesti”, Institutul European din România (IER), București.

ANRE (2009), Notificare către Comisia Europeană provind Ajutorul de Stat nr. 437/2009-România, Schema de ajutor de stat privind promovarea cogenerării.

Ministerul Economiei (2011), "Strategia energetică a României pentru perioada 2007-2020, actualizată pentru perioada 2011-2020". 